\title{
Neurohormones as Predictors of Outcome in an Elderly Heart Failure Population Naïve of Neurohormonal Blockers Results from the CIBIS III Neurohormonal Substudy
}

\author{
Friedrich M. Fruhwald*,1, Astrid Fahrleitner-Pammer ${ }^{2}$, Barbara Obermayer-Pietsch ${ }^{2}$, Michael A. \\ Goulder $^{3}$, Henry Krum ${ }^{4}$, Dirk J. van Veldhuisen ${ }^{5}$, Louis van de Ven ${ }^{6}$, Patricia Verkenne ${ }^{6}$, Burkert \\ Pieske $^{1}$, Wilfried Meyer ${ }^{6}$ and Ronnie Willenheimer ${ }^{7}$ \\ ${ }^{1}$ Department of Cardiology, Medical University Graz, Austria \\ ${ }^{2}$ Department of Endocrinology and Nuclearmedicine, Medical University Graz, Austria \\ ${ }^{3}$ Worldwide Clinical Trials, Nottingham, UK \\ ${ }^{4}$ Departments of Epidemiology and Preventive Medicine, Monash University, Melbourne, Australia \\ ${ }^{5}$ Thoraxcenter, Department of Cardiology, University Hospital Groningen, The Netherlands \\ ${ }^{6}$ Merck Serono, Darmstadt, Germany \\ ${ }^{7}$ Dept of Clinical Sciences Cardiology, Lund University and Heart Health Group, Malmoe, Sweden
}

\begin{abstract}
Objectives: Although neurohormones have a well-established prognostic value in patients with chronic heart failure (CHF), little is known about this in CHF patients untreated with angiotensin-converting enzyme (ACE)-inhibitors, angiotensin-receptor blockers (ARBs) and beta-blockers.

Methods: Baseline N-terminal pro atrial natriuretic peptide (NT-pro-ANP), N-terminal pro B-type natriuretic peptide (NTpro-BNP), big endothelin (big-ET) and arginine-vasopressin (AVP) were tested for prognostic importance to predict the primary endpoint (death or hospitalisation) in 109 patients participating in the third Cardiac Insufficiency BIsoprolol Study(CIBIS III). Minimum follow-up time was 12 months (6 months monotherapy followed by 6 months combinationtherapy).

Results: On average, patients had moderate elevation of all neurohormones tested. In univariate analysis, both belowmedian NT-pro-BNP (HR 0.37, 95\% confidence interval [CI] 0.17-0.81, p=0.013) and below-median big-ET (HR 0.39, $95 \%$ CI $0.18-0.86, \mathrm{p}=0.02$ ) predicted decreased risk of all-cause death or hospitalisation, compared with above-median values. NT-pro-BNP lost its predictive power in multivariate analysis, while big-ET above median as well as body mass index (BMI) below median and presence of ischemic heart disease were predictive of increased risk of death or hospitalisation. Using Cox stepwise regression analysis, only BMI ( $\mathrm{p}=0.011)$ and big-ET $(\mathrm{p}=0.003)$ remained significant predictors of death or hospitalisation.

Conclusion: In a cohort of elderly CHF patients naïve of ACE-inhibitors, ARBs and beta-blockers, the best predictors of all-cause death or hospitalisation were a low BMI and elevated levels of big-endothelin.
\end{abstract}

Keywords: Bisoprolol, enalapril, chronic heart failure, elderly patients, neurohormones.

\section{INTRODUCTION}

Treatment of chronic heart failure (CHF) is based on the concept of neurohumoral blockade of both the reninangiotensin-system (RAS) and the sympatho-adrenergic system (SAS). Guidelines recommend starting treatment with an angiotensin-converting-enzyme inhibitor (ACE-inhibitor) or an angiotensin receptor blocker (ARB) and later adding a beta-blocker [1]. However, the results of the third Cardiac Insufficiency BIsoprolol Study (CIBIS III) suggest that it is

*Address correspondence to this author at the Department of Cardiology, University Clinic of Internal Medicine, Auenbruggerplatz 15, A-8036 Graz, Austria; Tel: +43/316/385-2544; Fax: +43/316/385-3733;

E-mail: friedrich.fruhwald@meduni-graz.at reasonable to start with the beta-blocker bisoprolol in elderly patients naïve of RAS-blockers [2].

Neurohormones, such as natriuretic peptides are among the best-investigated predictors of prognosis in patients with both acute and chronic heart failure [3-5]. However, the majority of the randomised controlled trials from which these data emerged requested pre-treatment with ACE-inhibitors. Little is known about the prognostic value of neurohormones in CHF patients untreated with ACE-inhibitors, ARBs and beta-blockers.

We investigated neurohumoral parameters in the CIBIS III trial to elucidate the context of neurohormones and prognosis in elderly patients untreated with neurohormonal blockers. 


\section{PATIENTS AND METHODS}

\subsection{The CIBIS III Investigation}

CIBIS III was a multinational study with a prospective, randomized, open-label blinded endpoint evaluation (PROBE) design, including patients with mild to moderate CHF (New York Heart Association [NYHA] class II or III), at least 65 years old. Patients had to be naïve for treatment with ACE-inhibitors, ARBs and beta-blockers within 3 months before entering the study. Patients were randomized to start treatment with either bisoprolol or enalapril for around six months as monotherapy followed by at least six months of combined therapy [6]. The major results of CIBIS III have been published [2]. In brief, 1010 patients were randomized and uptitrated towards a target dose of bisoprolol (target $10 \mathrm{mg} /$ day) or enalapril (target $20 \mathrm{mg} /$ day). The intention-to-treat analysis showed non-inferiority of bisoprolol as first-line drug, compared with enalapril, in terms of the primary endpoint of all-cause death or hospitalisation.

The neurohumoral substudy of CIBIS III included 109 patients (60 randomised to bisoprolol-first and 49 randomised to enalapril-first) recruited in centres willing to participate and able to store the samples at $-70^{\circ} \mathrm{C}$. At baseline, at the end of the monotherapy phase and at study end, samples of $7.0 \mathrm{ml}$ of blood were drawn into chilled tubes containing EDTA-plasma. Vials were immediately put into ice-cold water and centrifuged at $-4^{\circ} \mathrm{C}$ at $4000 \mathrm{rpm}$ for at least 10 minutes. Supernatant plasma was aliquoted and stored in labelled vials at $-70^{\circ} \mathrm{C}$ until the end of the CIBIS III study. Finally, vials were transported on dry ice using a courierservice to the neurohumoral core-laboratory (Medical University Graz). After a check on delivery (frozen status, accurate labelling) they were kept frozen at $-70^{\circ} \mathrm{C}$ until analysis after completion of the CIBIS III study.

$\mathrm{N}$-terminal pro B-type natriuretic peptide (NT-pro-BNP) was measured using a commercially available electrochemiluminescence immunoassay (ECLIA) based on a polyclonal antibody-based sandwich chemiluminescence assay (Roche Diagnostics, Germany). Normal values in a healthy population are $<125 \mathrm{pg} / \mathrm{ml}$ with a lowest detection limit of $<5$ $\mathrm{pg} / \mathrm{ml}$.

$\mathrm{N}$-terminal pro-atrial natriuretic peptide (NT-pro-ANP) was measured using a commercially available enzyme linked immuno assay (ELISA, Biomedica Austria). Normal values in a healthy population are $<1.45 \mathrm{nmol} / \mathrm{l}$ with a lowest detection limit of $0.05 \mathrm{nmol} / \mathrm{l}$.

Big-endothelin (big-ET) was measured using a commercially available ELISA (Biomedica Austria). Normal values in a healthy population are $<0.20 \mathrm{fmol} / \mathrm{ml}$ with a lowest detection limit of $0.020 \mathrm{fmol} / \mathrm{ml}$.

Table 1. Baseline Characteristics of the CIBIS III Patients Participating in the Neurohumoral Analysis

\begin{tabular}{|c|c|c|c|}
\hline Variable & $\begin{array}{c}\text { Entire Patient Population } \\
(n=109)\end{array}$ & $\begin{array}{c}\text { Bisoprolol-First Group } \\
(n=60)\end{array}$ & $\begin{array}{c}\text { Enalapril-First Group } \\
(n=49)\end{array}$ \\
\hline Median age, years (IQR) & $73(68-78)$ & $73(68-77)$ & $73(68-78)$ \\
\hline Median Heart Rate, bpm (IQR) & $76(70-88)$ & $78(71.5-88.0)$ & $75(70-86)$ \\
\hline Median Systolic Blood Pressure, mm Hg (IQR) & $135(120-145)$ & $140(125-146)$ & $130(120-140)$ \\
\hline Median LV-ejection fraction (IQR) & $29(25-32)$ & $30(26.0-33.5)$ & $25(23-30)$ \\
\hline NYHA class II, n (\%) & $55(50)$ & $28(47)$ & $27(55)$ \\
\hline NYHA class III, $\mathrm{n}(\%)$ & $54(50)$ & $32(53)$ & $22(45)$ \\
\hline Median BMI, kg/m², (IQR) & $25.8(23.4-28.4)$ & $26.2(23.6-28.4)$ & $25.7(23.0-28.6)$ \\
\hline Ischemic heart disease, $\mathrm{n}(\%)$ & $55(50)$ & $29(48)$ & $26(53)$ \\
\hline Hypertension, $\mathrm{n}(\%)$ & $37(34)$ & $22(37)$ & $15(31)$ \\
\hline Valvular disease, n (\%) & $4(4)$ & $3(5)$ & $1(2)$ \\
\hline Primary dilated cardiomyopathy, n (\%) & $16(15)$ & $10(17)$ & $6(12)$ \\
\hline Other, n (\%) & $20(18)$ & $11(18)$ & $9(18)$ \\
\hline Median NT-pro-BNP, pg/ml (IQR) & $1592(570-3596)$ & $1170(554-3596)$ & $1664(656-3585)$ \\
\hline Median NT-pro-ANP, nmol/l (IQR) & $5.3(2.13-8.65)$ & $5.3(1.75-7.24)$ & $6.1(3.20-8.80)$ \\
\hline Median big-ET, fmol/ml (IQR) & $0.52(0.36-0.77)$ & $0.56(0.37-0.77)$ & $0.48(0.32-0.76)$ \\
\hline
\end{tabular}

Abbreviations: IQR = Inter-Quartile Range; LV = left ventricular; BMI = body mass index; NT-pro-BNP = N-terminal pro B-type natriuretic peptide; NT-pro-ANP = N-terminal pro-atrial natriuretic peptide; big-ET=big endothelin; AVP=arginine-vasopressin. 
Arginine-Vasopressin (AVP) was measured using a commercially available double antibody radioimmuno-assay (Bühlmann Laboratories AG, Switzerland). Normal values in a healthy population are $<7.6 \mathrm{pg} / \mathrm{ml}$ with a lowest detection limit of $1.3 \mathrm{pg} / \mathrm{ml}$ (to convert into pmol/L multiply by 0.92 ).

\subsection{Statistics}

Descriptive statistics were calculated for demographic data, vital-parameters and NYHA-classification. All neurohumoral variables were non-normally distributed.

A significance level of $5 \%$ was used for all tests, which were performed using SAS (version 9.1).

With NT-pro-BNP being the best investigated neurohormone in $\mathrm{CHF}$ today we divided patients into quartiles according to baseline NT-pro-BNP. For demographic vari- ables, a p-value for a trend amongst the quartile groups was calculated by using the Cochran-Armitage trend test (binary variables) or the Spearman's correlation coefficient (continuous variables).

The relationships between each baseline variable of interest and the primary endpoint (death or hospitalisation) were investigated by a series of univariate Cox regression models with each baseline variable considered as a two-level factor ( $\leq$ median, >median). The hazard ratios (HR) were calculated with the associated $95 \%$ confidence intervals. A $\mathrm{HR}>1$ indicated that there was a greater risk of the endpoint occurring within the subgroup having values $\leq$ median. Similar models were also fitted for gender, presence of ischemic heart disease and treatment allocation according to randomisation. Two multivariate Cox models were also fitted including all the baseline variables in the same model, firstly with-

Table 2. Baseline Characteristics of Patients According to Quartiles of Baseline NT-pro-BNP Levels (pg/ml)

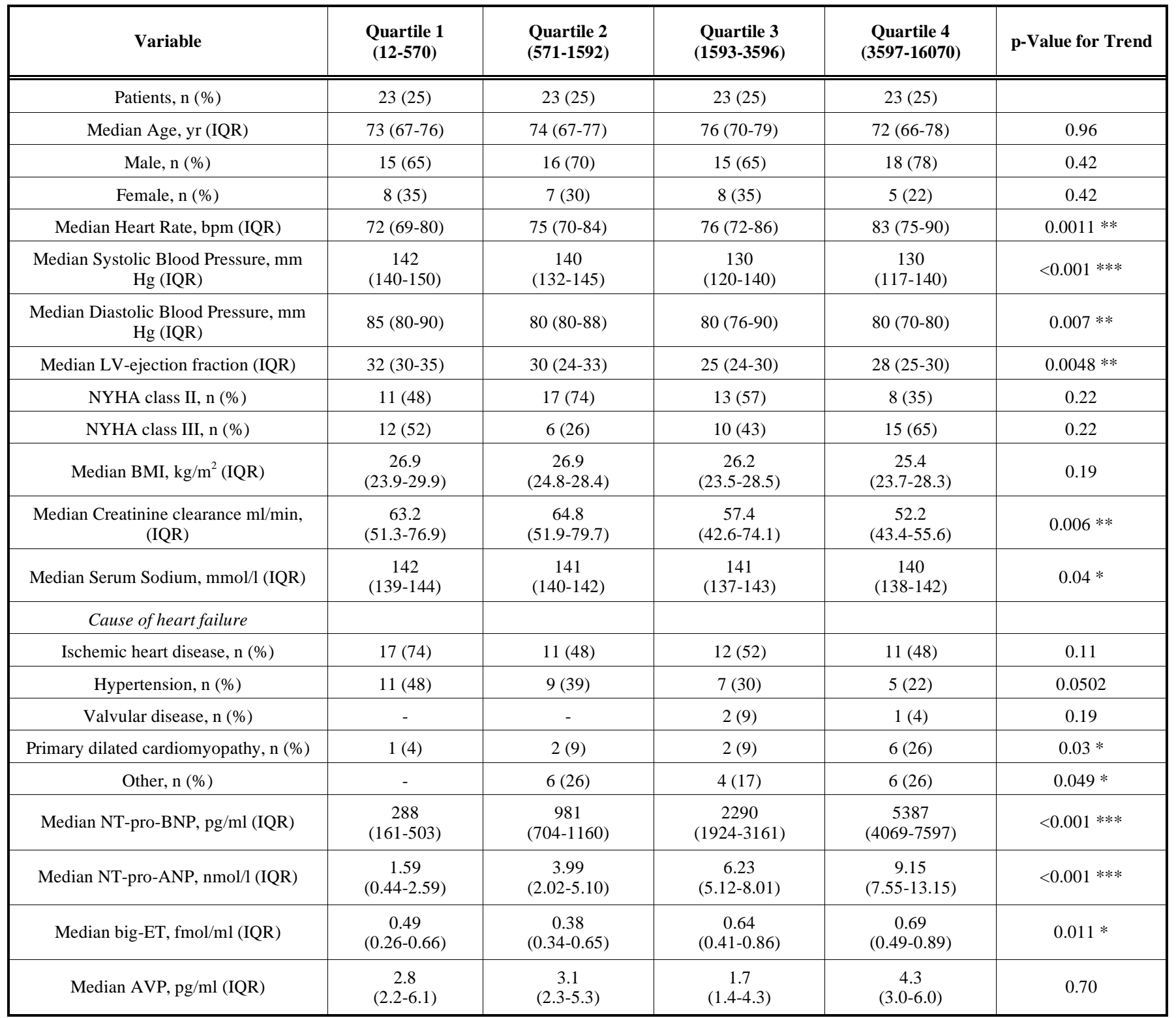

Abbreviations: IQR = Inter-Quartile Range; LV = left ventricular; BMI = body mass index; NT-pro-BNP = N-terminal pro B-type natriuretic peptide; NT-pro-ANP = N-terminal pro-atrial natriuretic peptide; big-ET=big endothelin; AVP=arginine-vasopressin.

$*: \mathrm{p}<0.05 ; * *: \mathrm{p}<0.01 ; * * *: \mathrm{p}<0.001$. 
out regard to selection procedures and secondly using a stepwise regression procedure with a $5 \%$ significance level of entry into the model.

Changes of the four neurohumoral variables from baseline to the end of monotherapy and to the end of the study, respectively, were assessed using one-way analysis of covariance on ranked-transformed data with a factor for treatment group and baseline value as a covariate.

\section{RESULTS}

Overall 32 of 128 centres (25\%) were able to participate in the neurohumoral substudy. These centres included 109 patients for analysis of neurohormones. Baseline characteristics of patients included in the neurohormonal analysis did not differ between the two treatment groups, with the exception of LVEF that was higher in the bisoprolol-first group (Table 1). All neurohormones were clearly elevated at study entry and did not differ between treatment groups.

Patients $(n=92)$ were divided into quartiles with regard to baseline levels of NT-pro-BNP. There was a statistically significant difference between quartiles regarding median resting heart rate, blood pressure, left ventricular ejection fraction, renal function and serum sodium concentration. With respect to neurohormones NT-pro-ANP and big-ET increased parallel to quartiles of NT-pro-BNP, while AVP did not show a significant trend (Table 2 ).

The probabilities of reaching the primary endpoint according to quartiles of baseline NT-pro-BNP are shown in Fig. (1). Clearly, higher NT-pro-BNP levels at baseline were associated with poor prognosis.

In a univariate analysis of baseline parameters only NTpro-BNP and big-ET above median statistically significantly predicted increased risk of the primary endpoint. All other parameters including age, heart rate, systolic blood pressure, body mass index (BMI), renal function, serum sodium concentration, NT-pro-ANP, AVP, gender, ischemic heart disease and treatment allocation (bisoprolol or enalapril first) were not statistically significant predictors (Table $\mathbf{3}$ ).

However, the multivariate model showed that BMI below median $\left(25.8 \mathrm{~kg} / \mathrm{m}^{2}\right)$, big-ET above median $(0.52 \mathrm{fmol} / \mathrm{ml})$

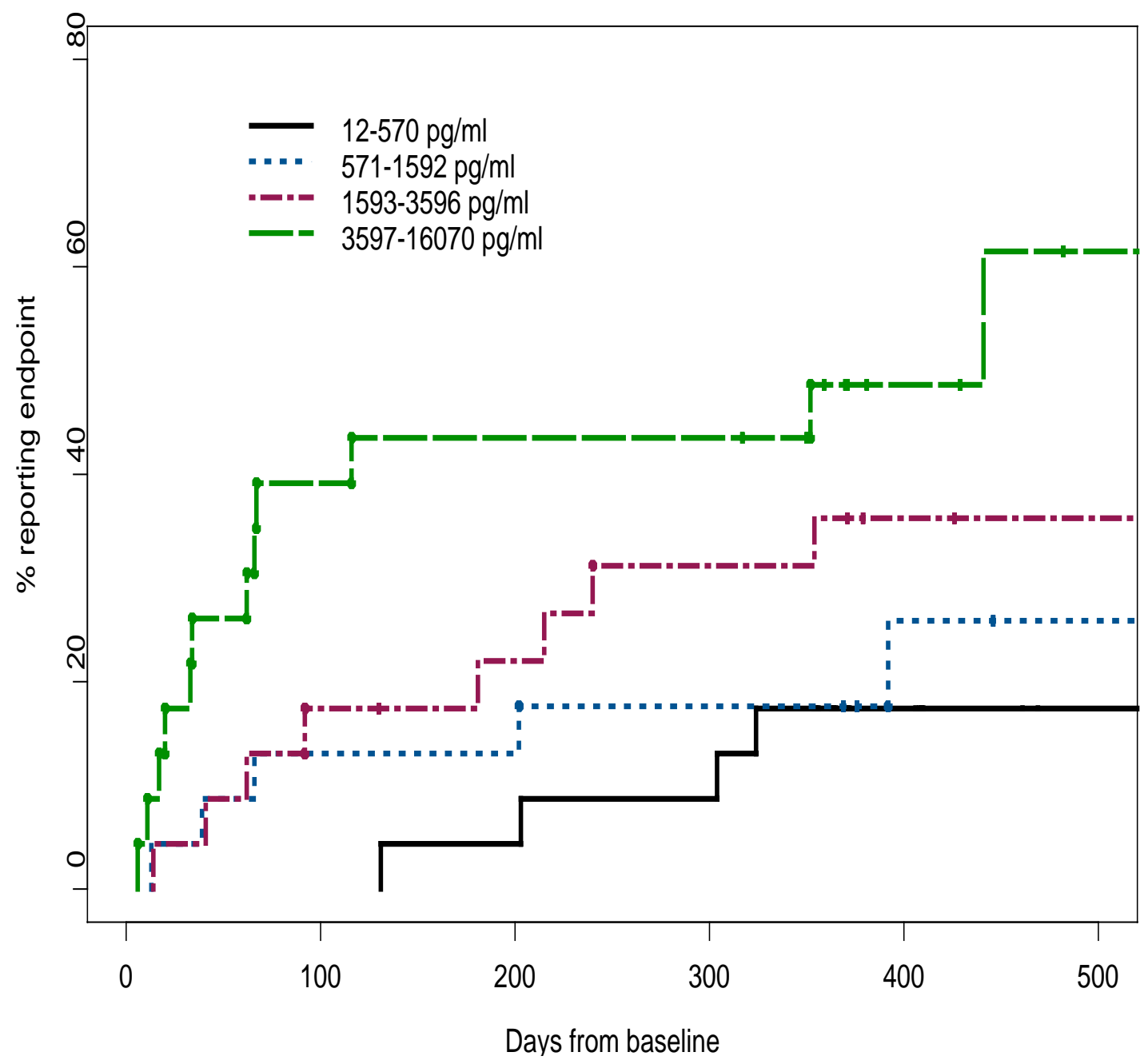

Fig. (1). Kaplan-Meier Curve for the combined primary endpoint (death or hospitalisation) according to Quartiles of baseline NTpro-BNP levels $(n=92)$ at study entry.

There was a significant between-quartile difference $(\mathrm{p}=0.02)$ : the higher baseline NT-pro-BNP the higher the risk of death or hospitalisation. Kaplan-Meier mean estimates to time to reporting of endpoint in days were: 309.5 days (12-570 pg/ml), 337.3 days (571-1592 pg/ml), 282.0 days (1593-3596 pg/ml) and 263.5 days $(3597-16070 \mathrm{pg} / \mathrm{ml})$. 
Table 3. Univariate Analysis of Baseline Predictors of the Primary Endpoint (Death or Hospitalisation)

\begin{tabular}{|c|c|c|c|c|c|}
\hline Variable & $\begin{array}{l}\text { Number }(\%) \text { of Total } \\
\text { Reporting Endpoint } \\
\leq \text { Median }\end{array}$ & $\begin{array}{c}\text { Number }(\%) \text { of Total } \\
\text { Reporting Endpoint } \\
>\text { Median }\end{array}$ & $\begin{array}{c}\text { Hazard } \\
\text { Ratio (HR) }\end{array}$ & $\begin{array}{l}\text { 95\% Confidence } \\
\text { Interval (CI) }\end{array}$ & p-Value \\
\hline $\begin{array}{c}\text { Heart Rate } \\
(\text { median }=76 \mathrm{bpm})\end{array}$ & $17 / 56(30)$ & $20 / 53(38)$ & 0.73 & $0.38,1.40$ & 0.35 \\
\hline $\begin{array}{l}\text { Systolic Blood Pressure } \\
\text { (median = } 135 \mathrm{mmHg} \text { ) }\end{array}$ & $23 / 56(41)$ & $14 / 53(26)$ & 1.85 & $0.95,3.59$ & 0.07 \\
\hline $\begin{array}{c}\text { BMI } \\
\left(\text { median }=25.8 \mathrm{~kg} / \mathrm{m}^{2}\right)\end{array}$ & $23 / 55(42)$ & $14 / 54(26)$ & 1.76 & $0.91,3.42$ & 0.10 \\
\hline $\begin{array}{l}\text { Creatinine clearance } \\
(\text { median }=57.3 \mathrm{ml} / \mathrm{min})\end{array}$ & $22 / 55(40)$ & $15 / 54(28)$ & 1.62 & $0.84,3.12$ & 0.15 \\
\hline $\begin{array}{c}\text { NT-pro-BNP } \\
(\text { median }=1592 \mathrm{pg} / \mathrm{ml})\end{array}$ & $9 / 46(20)$ & $20 / 46(43)$ & 0.37 & $0.17,0.81$ & $0.013^{*}$ \\
\hline $\begin{array}{c}\text { NT-pro-ANP } \\
(\text { median }=5.3 \mathrm{nmol} / \mathrm{l})\end{array}$ & $12 / 49(24)$ & $21 / 48(44)$ & 0.50 & $0.24,1.01$ & 0.053 \\
\hline $\begin{array}{c}\text { Big-ET } \\
(\text { median }=0.52 \mathrm{fmol} / \mathrm{ml})\end{array}$ & $9 / 45(20)$ & $20 / 45(44)$ & 0.39 & $0.18,0.86$ & $0.02 *$ \\
\hline $\begin{array}{c}\text { AVP } \\
(\text { median }=3.1 \mathrm{pg} / \mathrm{ml})\end{array}$ & $20 / 54(37)$ & $15 / 53(28)$ & 1.48 & $0.76,2.89$ & 0.25 \\
\hline Ischemic heart disease & bisoprolol-first & enalapril-first & & & \\
\hline Treatment allocation & $23 / 60(38)$ & $14 / 49(29)$ & 1.37 & $0.70,2.66$ & 0.35 \\
\hline
\end{tabular}

Abbreviations: $\mathrm{BMI}=$ body mass index; NT-pro-BNP = N-terminal pro B-type natriuretic peptide; NT-pro-ANP = N-terminal pro-atrial natriuretic peptide; big-ET=big endothelin; AVP=arginine-vasopressin.

$*: \mathrm{p}<0.05 ; * *: \mathrm{p}<0.01 ; * * *: \mathrm{p}<0.001$

and presence of ischemic heart disease significantly predicted death or hospitalisation (Table 4). Using a stepwise regression model, the factors kept in the model using a $5 \%$ significance level to predict the primary endpoint were a low BMI and an elevated big-ET.

Overall $37(34 \%)$ patients who were included into the univariate analyses reached the primary endpoint throughout the study period. Due to missing data, 85 subjects were included in the multivariate analysis with $26(31 \%)$ reporting the primary endpoint.

When looking at changes during the trial of the four tested neurohormones, we found no statistically significant changes. NT-pro-BNP decreased in both treatment groups during the six-month monotherapy phase and returned to baseline levels at the end of the trial. NT-pro-ANP decreased during monotherapy in the enalapril-first group only and returned to baseline levels at study end. Values for big-ET and AVP remained stable throughout the entire study period in both treatment arms.

\section{DISCUSSION}

This ancillary study of CIBIS III shows that, in elderly $\mathrm{CHF}$ patients naïve of ACE-inhibitors, ARBs and betablockers, baseline values of low BMI and high big-ET as well as presence of ischemic heart disease are independent predictors of all-cause death or hospitalisation.

Not surprisingly, NT-pro-BNP-data confirm that patients studied in CIBIS III suffered from mild to moderate CHF. However, while there were some patients with NT-pro-BNP- 
Table 4. Multivariate Analysis of Baseline Predictors of the Primary Endpoint (Death or Hospitalisation)

\begin{tabular}{|c|c|c|c|}
\hline Age $\leq 73$ years & 2.46 & $0.90,6.75$ & 0.08 \\
\hline Heart Rate $\leq 76$ bpm & 0.94 & $0.39,2.27$ & 0.89 \\
\hline $\mathrm{BMI} \leq 25.8 \mathrm{~kg} / \mathrm{m}^{2}$ & 5.87 & $1.94,17.80$ & $0.002 * *$ \\
\hline Calculated creatinine clearance $\leq 57.3 \mathrm{ml} / \mathrm{min}$ & 1.47 & $0.47,4.60$ & 0.51 \\
\hline Serum Sodium $\leq 141 \mathrm{mmol}(1$ & 1.50 & $0.59,3.80$ & 0.39 \\
\hline Ischemic heart disease & 2.73 & $1.03,7.22$ & $0.04 *$ \\
\hline NT-pro-ANP $\leq 5.3 \mathrm{nmol} / 1$ & 1.15 & $0.36,3.68$ & 0.81 \\
\hline Big-ET $\leq 0.52 \mathrm{fmol} / \mathrm{ml}$ & 0.20 & $0.07,0.59$ & $0.004 * *$ \\
\hline $\mathrm{AVP} \leq 3.1 \mathrm{pg} / \mathrm{ml}$ & 2.20 & $0.86,5.64$ & 0.10 \\
\hline
\end{tabular}

The factors kept in the model using stepwise regression model with $5 \%$ significance level

\begin{tabular}{|c|c|c|c|c|c|}
\hline Variable & $\begin{array}{l}\text { Number (\%) of Total } \\
\text { Reporting Endpoint } \\
\leq \text { Median }\end{array}$ & $\begin{array}{c}\text { Number }(\%) \text { of Total } \\
\text { Reporting Endpoint } \\
>\text { Median }\end{array}$ & $\begin{array}{c}\text { Hazard } \\
\text { Ratio (HR) }\end{array}$ & $\begin{array}{l}\text { 95\% Confidence } \\
\text { Interval (CI) }\end{array}$ & p-Value \\
\hline Big-ET $\leq 0.52 \mathrm{fmol} / \mathrm{ml}$ & $7 / 43(16)$ & $19 / 42(45)$ & 0.26 & $0.11,0.63$ & $0.003 * *$ \\
\hline
\end{tabular}

Abbreviations: BMI = body mass index; NT-pro-BNP = N-terminal pro B-type natriuretic peptide; NT-pro-ANP = N-terminal pro-atrial natriuretic peptide; big-ET=big endothelin; $\mathrm{AVP}=$ arginine-vasopressin.

$*: \mathrm{p}<0.05 ; * *: \mathrm{p}<0.01 ; * * *: \mathrm{p}<0.001$

values suggesting mild $\mathrm{CHF}$, there was a considerable proportion of patients with NT-pro-BNP-values suggesting moderate to severe heart failure as well (those in the highest quartile of baseline NT-pro-BNP).

Natriuretic peptides have a long history in HF. Both ANP and BNP have been thoroughly investigated. Nowadays, BNP together with its N-terminal fragment NT-pro-BNP are preferred over ANP for diagnosis and prognostication of CHF patients [1]. However, the foremost-discovered NTpro-ANP correlates well with both clinical variables and with non-invasive measurements in $\mathrm{CHF}$ patients [7, 8]. BNP and NT-pro-BNP, which both can be measured easily by various commercially available ELISA-tests, are probably the best investigated laboratory parameters in CHF. They are helpful for diagnosis of patients with acute dyspnoea $[9,10]$, prognostication in patients with acute HF and CHF (3-5), and for monitoring therapeutic effects [11]. Recently it has been demonstrated that both intensified neurohumoral therapy and cardiac resynchronisation therapy can reduce NTpro-BNP over the long-run [12-14]. Interestingly, in our cohort of patients with mild to moderate CHF, NT-pro-BNP was only a predictor of death or hospitalisation (the primary endpoint of CIBIS III) in the univariate analysis of baseline parameters. It lost its prognostic power in the multivariate analysis and was replaced by BMI.

Big-ET, the precursor of the potent vasoconstrictor endothelin 1 , has been investigated in patients with moderate and advanced CHF. It is a potent prognostic marker for adverse outcome in the latter despite optimal chronic neurohumoral therapy [15-17]. Very recently, data from the Val-HeFT trial showed that big-ET was an independent marker of prognosis in a large population of patients with predominantly mild to moderate CHF [18], although its prognostic power was lower than that of BNP. In contrast, in our patient cohort multivariate analysis revealed that big-ET was better than NT-pro-BNP for prediction of death or hospitalisation. One possible reason for this discrepancy is that our patients were essentially untreated with ACE-inhibitors, ARBs and betablockers before randomisation. Another possible explanation is that our patients were substantially older than in almost all prior studies on the issue, including the Val-HeFT trial.

It is long known that cachexia is among the best predictors of adverse outcome in patients with CHF $[19,20]$. The early observational reports have been confirmed by reports from large, randomised trials: Low BMI is consistently a marker of morbidity and mortality in patients with $\mathrm{CHF}$ [21, 
22]. Therefore, our findings are in line with earlier reports. However, our patients with low BMI would correspond to the medium-risk group in the CHARM-population [22] and to the combined normal-weight and over-weight groups in the Val-HeFT-population, respectively [21]. Nevertheless, in our population, a BMI equal to or less than $25.8 \mathrm{~kg} / \mathrm{m}^{2}$ was associated with a 2.82 -fold risk of death or hospitalisation, as compared with a BMI of more than $25.8 \mathrm{~kg} / \mathrm{m}^{2}$.

Treatment allocation at randomisation (i.e. bisoprololfirst or enalapril-first) had no influence on death or hospitalisation, as previously reported for the entire CIBIS III patient sample [2].

\section{Limitations}

The major limitation of our report is that only a minority of centres was willing and able to participate in this substudy. Therefore, only a limited percentage of patients taking part in the main-study could be included into this ancillary study. Hence, results can be valid only for this small population and one must be cautious about generalising them. However, BMI results are available for the entire study population, revealing very similar results.

\section{CONCLUSION}

In a cohort of elderly CHF patients naïve of ACEinhibitors, ARBs and beta-blockers, the best predictors of death or hospitalisation were a low BMI and elevated levels of big-ET.

\section{ACKNOWLEDGEMENTS}

We are indebted to Mr. Christian Kasper for his expert analysis of blood samples.

This study was funded by an unrestricted research grant from Merck-Serono, Roche Diagnostics and Biomedica Austria.

Friedrich Fruhwald reported having received research grants for heart failure studies (incl. CIBIS III) and lecture fees from Merck Serono. Astrid Fahrleitner-Pammer reported having received research grants for heart failure studies (incl. CIBIS III) from Merck Serono. Henry Krum reported having received lecture fees from Merck Serono. Louis van de Ven, Patricia Verkenne and Wilfried Meyer are employees of Merck Serono. Ronnie Willenheimter reported having received fees for serving as chairman of CIBIS III as well as lecture fees and consultancy fees from Merck Serono. The other authors report no potential conflict of interest.

\section{REFERENCES}

[1] The Task Force for the Diagnosis and Treatment of Chronic Heart Failure of the ESC. Guidelines for the diagnosis and treatment of chronic heart failure: Executive summary. Eur Heart J 2005; 26: 115-40.

[2] Willenheimer R, van Veldhuisen DJ, Silke B, et al. Effect on survival and hospitalization of initiating treatment for chronic heart failure with bisoprolol followed by enalapril, as compared with the opposite sequence. Results of the randomized cardiac insufficiency bisoprolol study (CIBIS) III. Circulation 2005; 112: 2426-35.

[3] Gardner RS, Özalp FO, Murday AJ, Robb SD, McDonagh TA. Nterminal pro-brain natriuretic peptide. A new gold standard in predicting mortality inpatients with advanced heart failure. Eur Heart J 2003; 24: 1735-43.
[4] Hartmann F, Packer M, Coats AJS, et al. Prognostic impact of plasma N-terminal pro-brain natriuretic peptide in severe chronic congestive heart failure. A substudy of the Carvedilol Randomized Cumulative Survival (COPERNICUS) trial. Circulation 2004; 110: $1780-6$.

[5] Olsson LG, Swedberg K, Cleland JGF, et al. Prognostic importance of plasma NT-pro-BNP in chronic heart failure in patients treated with a B-blocker: Results from the Carvedilol Or Metoprolol European Trial (COMET) trial. Eur J Heart Fail 2007; 9: 795-801.

[6] Willenheimer R, Erdmann E, Follath F, et al. Comparison of treatment initiation with bisoprolol versus enalapril in chronic heart failure patients: Rationale and design of CIBIS III. Eur J Heart Fail 2004; 6: 493-500.

[7] Dickstein K, Larsen AI, Bonarjee V, Thoresen M, Aarsland T, Hall C. Plasma proatrial natriuretic factor is predictive of clinical status in patients with congestive heart failure. Am J Cardiol 1995; 76: 679-83.

[8] Hall C, Kjekshus J, Eneroth P, Snapinn S. The plasma concentration of N-terminal proatrial natriuretic factor $\operatorname{ANF}(1-98)$ is related to prognosis in severe heart failure. Clin Cardiol 1994; 17: 191-5.

[9] Maisel AS, Krishnaswamy P, Nowak RM, et al. Rapid measurement of B-type natriuretic peptide in the emergency diagnosis of heart failure. N Engl J Med 2002; 347: 161-7.

[10] Januzzi JL, Camargo CA, Anwaruddin S, et al. The N-terminal pro-BNP investigation of dyspnea in the emergency department (PRIDE) study. Am J Cardiol 2005; 95: 948-54.

[11] McDonagh TA, Robb SD, Murdoch DR, et al. Biochemical detection of left ventricular systolic dysfunction. Lancet 1997; 351: 913.

[12] Murdoch DR, McDonagh TA, Byrne J, et al. Titration of vasodilator therapy in chronic heart failure according to plasma brain natriuretic peptide concentration: Randomized comparison of the hemodynamic and neuroendocrine effects of tailored versus empirical therapy. Am Heart J 1999; 138: 1126-32.

[13] Troughton RW, Frampton CM, Yandle TG, Espiner EA, Nicholls MG, Richards AM. Treatment of heart failure guided by plasma aminoterminal brain natriuretic peptide (N-BNP) concentrations. Lancet 2000; 366: 1126-30.

[14] Fruhwald FM, Fahrleitner-Pammer A, Berger R, et al. Early and sustained effects of cardiac resynchronisation therapy on $\mathrm{N}$ terminal pro-B-type natriuretic peptide in patients with moderate to severe heart failure and cardiac dyssynchrony. Eur Heart J 2007; 28: $1592-7$.

[15] Pacher R, Stanek B, Hülsmann M, et al. Prognostic impact of big endothelin-1 plasma concentrations compared with invasive hemodynamic evaluation in severe heart failure. J Am Coll Cardiol 1996; 27: 633-41.

[16] Hülsmann M, Stanek B, Frey B, et al. Value of cardiopulmonary exercise testing and big endothelin plasma levels to predict shortterm prognosis of patients with chronic heart failure. J Am Coll Cardiol 1998; 32: 1695-1799.

[17] Stanek B, Frey B, Hülsmann M, et al. Prognostic evaluation of neurohumoral plasma levels before and during beta-blocker therapy in advanced left ventricular dysfunction. J Am Coll Cardiol 2001; 38: 436-42.

[18] Masson S, Latini R, Anand IS, et al. The prognostic value of bigendothelin 1 in more than 2,300 patients with heart failure enrolled in the Valsartan Heart Failure Trial (Val-HeFT). J Card Fail 2006; 12: 375-80.

[19] Anker SD, Ponikowski P, Varney S, et al. Wasting as independent risk factor for mortality in chronic heart failure. Lancet 1997; 349: 1050-3.

[20] Horwich TB, Fonarow GC, Hamilton MA, MacLellan WR, Woo MA, Tillisch JH. The relationship between obesity and mortality in patients with heart failure. J Am Coll Cardiol 2001; 38: 789-95.

[21] Cicoira M, Maggioni AP, Latini R, et al. Body mass index, prognosis and mode of death in chronic heart failure: Results from the Valsartan Heart Failure Trial. Eur J Heart Fail 2007; 9: 397-402. 
[22] Kenchaiah S, Pocock SJ, Wang D, et al. Body mass index and prognosis in patients with chronic heart failure. Insights from the Candesartan in Heart Failure: Assessment of Reduction in Mortal- ity and morbidity (CHARM) program. Circulation 2007; 116: 62736

(C) Fruhwald et al.; Licensee Bentham Open.

This is an open access article licensed under the terms of the Creative Commons Attribution Non-Commercial License (http://creativecommons.org/licenses/by-nc/3.0/) which permits unrestricted, non-commercial use, distribution and reproduction in any medium, provided the work is properly cited. 